Work Employment and Society 23 (1) 2009. Accepted rev'd version.

\title{
Stuck in the middle with who? The class identity of knowledge workers
}

\author{
Abigail Marks* and Chris Baldry\# \\ * Heriot Watt University \\ \# University of Stirling
}

\begin{abstract}
The coming of the information age has been associated with widespread social transformation and new, or dissolved, class structures. Central to this claim is the emergence of 'knowledge workers' including information technology professionals. While previous discussion has focused on the paradox faced by IT workers as both professionals and employees, this paper using empirical data from five software organizations in Scotland, examines their perceptions of class structure and their own class position. We found participants clearly retained varying class models of society but expressed conflict between their own self-rated class identity and that which they awarded to their occupation and profession.
\end{abstract}

\section{Key words}

Class/IT/knowledge work/middle strata

\section{Introduction}

From the late eighteenth century, changing perceptions of social class have been seen as a key indicator of changes in social structure. The social class debate over the past century has consequently mirrored changes in the profile and structure of the labour force. Recent resurgence of analysis has been occasioned by the growth of white collar employment, the expansion of the formal education system, the shift from manufacturing to services and the rise of new forms of technical labour. The withering away of once prominent social groups and the rise of new ones have regularly been hailed as either the end of class society (e.g. Bell, 1979) or as the emergence of new social classes and class relationships. The latest incarnation of such predictions has been in the form of the claimed rise of the knowledge society and the rise to prominence of that rather hazily-defined group, knowledge workers (Drucker, 1998). 
Work Employment and Society 23 (1) 2009. Accepted rev'd version.

A number of arguments have been put forward over the past ten years as to why the knowledge society heralds the death of class. Rifkin (1995) for example, traces the end of the working class to the demise of manufacturing and agricultural employment. From his perspective, the introduction of new technologies have enabled organizations to increase output and productivity thanks to a new 'knowledge elite'. Pakulski and Waters suggested that in post-industrial society, discredited and outdated conceptions of class have been replaced by 'status conventional' social characteristics such as gender, ethnicity, age, religion and importantly, consumption behaviours. Similarly, Bauman (1998) argued that modern society has ended the notion of class identity, as the group in society previously known as the 'working class were no longer required as producers of goods and services but solely as consumers' and who construct for themselves temporary 'aggregate identities... (from what) is currently available in the shops'. Other writers have argued, conversely, that whilst traditional class identity is dead, a new elite has emerged who control information and are themselves a new social class (Bell, 1980).

This paper explores the class related attitudes of members of this supposed 'new elite' by taking a sample of Scottish software developers as archetypes for the knowledge worker. We attempt to extract some conclusions on technical workers' images of society and class identity and their self-location in that structure. Our argument commences with a review of the role of the middle strata and of the location of software workers within the class structure. We follow with a discussion of the contemporary debates on class and class identity, focusing on both class as a cultural entity and class as a position in a system of employment relations. This is preceded by an examination of how software workers understand class formation in Britain, how they locate themselves within class structures and the reasons they bring into play for their self-location. As Byrne (2005) suggests, class analysis should not only be concerned with economic and production relations, but should also account for the (potentially contradictory) self-identification of individuals in class structures and the trajectories of individuals and families through the process of social mobility.

\section{The Middle Strata, Knowledge Workers and Software Employees}


Work Employment and Society 23 (1) 2009. Accepted rev'd version.

Knowledge workers are part of that very mixed bag of occupations and social identities often referred to as the middle strata. This grouping has always presented a problem for class analysis. For many years the working-class/middle-class distinction was held to be synonymous with the manual/white-collar divide. White collar groups therefore included everyone from routine clerical workers to senior management, plus those groups seen as the professions. For this reason Smith and Willmott (1991) reject the term class for this group as implying too much homogeneity and instead prefer the term 'middle grouping'. For others authors however, the middle groups have been described variously as 'the service class,' (Goldthorpe, 1996) 'the new class' and the 'professional-managerial class' (Ehrenreich and Ehrenreich, 1979). Among the distinguishing characteristics that have at various times been seen as marking them off from other strata we can identify: the often 'unproductive' nature of their labour, the presence of managerial elements in their work, the enjoyment of different terms and conditions from other employees, and the role of enhanced career and life chances.

Much debate over this heterogeneous grouping surrounds the attempts to define an objective class position and the awareness that this is likely to be very different from any self-attributed position. In the Marxian tradition, classes are defined by the relationships between them. A class is not a self-contained entity - you cannot have a bourgeoisie without a proletariat. The task for those attributing an objective class identity to the middle strata has therefore always been to ask where does the relational boundary fall? This has resulted in long and tortuous debates (not reproduced here) about the distinction between productive and unproductive labour, where the first directly produces surplus value through the production of goods and services while the latter helps to realise that value by administering capital owned by others. On this basis, all the middle strata (technical and supervisory grades for example) could be seen as partially involved in performing the capitalist function. However, as Hyman (1983) pointed out, this attempt at a neat structural divide ignores the historical complexity: many skilled tradesmen and work-gang leaders often 'hired' and had supervisory control over their own gang members or unskilled helpers and could therefore also be said to have exercised a quasi-employer function. Similarly, in many an office today, a supervisor or team leader acts as an agent of capital yet experiences some aspects of being a worker. 
Work Employment and Society 23 (1) 2009. Accepted rev'd version.

Even if we accept any of the above boundary lines, it proves difficult to apply them to software workers particularly if, as Darr and Warhurst (2008) rightly argue, we include an analysis of their work. Traditional class theories would often base class on simple location of work (e.g. Klingender, 1935). That is, tasks undertaken in a boiler suit on a factory floor versus tasks undertaken in a suit in an office somehow placed individuals in different class categories. This has clearly not been a practical distinction for some time. With the introduction of IT systems across all work places, tasks are increasingly similar - interfacing with computer systems, whether in process control, high quality colour printing or selling insurance. In addition, the office is no longer only a place where services are provided for we can now make things in an office, such as software programmes. Thus, for technical professionals such as software developers, we can eliminate debates about productive or unproductive labour, or between production and services. Software employees are producing a product - a software package or system. The sale price of that product will encapsulate their surplus value.

This confusion however, leads us to more questions than answers. As they are creating a product, does this make software workers members of the working class? If so, are technical workers destined to become the vanguard of a new working class? Mallet (1975) long ago proposed this, using the productive labour benchmark: does the technician's job perform a productive function while being separate from the actual direction of the labour process? Or, with the increase in accessibility and ease of use of software systems, is this an occupation previously thought, because of their status position and differentials in remuneration and reward, to be vaguely middle class but now becoming working class? The proletarianisation thesis, first offered by Klingender (1935), argues that, if the deskilling of white-collar jobs and reduction of career opportunities or trajectories erode these social markers, then many of the white collar groups should be regarded as working class.

Alternatively, it could be argued that software workers, dissimilar from traditional production workers in education, increasing career opportunities, and residential patterns, are becoming more middle class. It was a similar 'embourgoisement' proposition that Goldthorpe and Lockwood set out to test in the 1960s Luton studies. These studies will be referred to throughout this paper as they provide an interesting 
Work Employment and Society 23 (1) 2009. Accepted rev'd version.

comparison. Undertaken at a time of socio-economic change, when there were widespread (but untested) assumptions about the withering away of the working class, the affluent workers of Luton were chosen because of the open access which these occupations offered. As the authors argued at the time, if embourgoisement could not be discerned in such a group then it probably was not happening anywhere (Goldthorpe et al, 1969). Turning the same logic towards the study of our prototypical knowledge workers, we could argue that, if software developers are still found to hold images of class in both societal and self-locational terms, then class is still alive and well as one of the parameters for social action.

Clearly, the role of software employees places them in a somewhat paradoxical structural position. To confuse matters even more, there is significant diversity within software work, which ranges from the routine to the cutting edge (Barrett, 2001). In a sense, it could be argued that software workers are part of a group that cuts across the intermediate/more traditional middle class divisions. Whilst this grouping is officially NS-SEC class 3 and perhaps class 2 (lower professional and managerial), there is a clear overlap with Goldthorpe's (1987) 'service class'. At the lower skilled end, they could be seen as members of a hazy and rather ill-defined grouping of those in routinised administrative occupations. Previous research has pointed to widespread evidence of specialisation and a fragmentation of the occupation, including the deskilling of jobs and extension of bureaucratic control (Barrett, 2001; Kraft and Dubnoff, 1986). Outwardly, at least, software work appears to have been subjected to a 'scientific management of mindwork' (Kraft and Dubnoff, 1986).

Nonetheless, they do share some characteristics with the 'service class' model which, unlike traditional professional groups or classes, has a low degree of social closure. Many software workers do not possess IT related qualifications and work across a variety of industrial sectors (Marks and Scholarios, 2007). Yet it is wrong to see them as part of the service sector: as argued above, these people are producing a product - a software package or system - rather than a service, and their own terminology and nomenclature derives from that of electronic engineering rather than white-collar services. Such variation in the nature of work may suggest heterogeneity in class position. Yet, we would argue that despite such dissimilarity in types of work and in 
Work Employment and Society 23 (1) 2009. Accepted rev'd version.

qualifications, these workers are all part of the group of occupations that are referred to as knowledge workers.

\section{Contemporary Perspectives on Class and Class Identity}

If software workers' structural position can seem contradictory, so too are their class perceptions and self-identification. In a special issue of Sociology Savage (2005) describes three main states in the contemporary study of class. The first of these phases evolved in the 1950s and 60s where class consciousness was seen to underpin research and theorising in the field. Work in the intermediate phase - much of which is touched upon in the previous section - was concerned with stratification, in terms of mobility. As Surridge (2007) notes, the final stage returns to a focus on individual's awareness of class, where class subjectivities previously referred to as consciousness are now considered in reference to class identity. Thus, earlier and later phases of class research have focused on subjective notions of class and this will be the perspective of this paper.

Some writers argue that one of the reasons that academics are losing their fascination with class is due to the replacement of a concern with class conflict by a focus on identity struggles (Bonney, 2007). Crompton (1998) however, has led the way with calls for a re-conceptualisation of class which includes a "closer investigation of both interests and identities' (Crompton and Scott, 2005, p.5). Devine and Savage (2000) argue that, although thinking in class terms may not necessarily be one and the same as the class consciousness necessary for the creation of political action, it does reveal an awareness of class as a reality and can be based within objective phenomena such as occupational groupings and income. Class processes may have become less visible and more implicit, but the effects of class are still pervasive in people's lives (Bottero, 2004). Devine (1998) argues that instead of class being defined in terms of employment relations, class should be viewed as 'collectives of people who share identities and practices' (p.23).

Such an approach can be associated with Stephenson and Stewart's (2001) notion of 'collectivism of everyday life', which McBride (2008) argues refers to friendship 
Work Employment and Society 23 (1) 2009. Accepted rev'd version.

support and care offered outside the workplace. McBride (2008) along with other writers in the field (e.g. Danford et al, 2003), suggests that the notion of the collective worker needs to be reconceptualised as there is too simplistic a dichotomy between individualism and collectivism - with a relatively stereotypical version of collectivism based on trade union activity and membership. Returning to Stephenson and Stewart (2001), they attempt to overcome this uni-dimensional treatment of collectivism by not only identifying 'collectivism of everyday life' but also a more traditional 'trade union collectivism' and 'workplace collectivism' which refers to the willingness of employees to provide support to one another in the workplace. Looking at alternative forms of collectivism helps us understand the notion of class as a form of attachment, rather than something that is necessarily embedded in structural workplace relations.

This 'culturalist' perspective holds that class identity is subjective and is embedded in cultural phenomena rather than objective structures and economic privileges (Devine and Savage, 2000; Reay, 1998). One reason that class is a notoriously slippery concept is that while it can be, and has been, used as a fundamental concept for analysing social structure, it is also recognised as an important part of that bundle of loyalties, shared experiences and common values that comprises an individual's social identity. From the earliest years of social investigation we have known that people seldom (or only at particular historical moments) judge themselves relative to other groups in society by their economic relationships alone. Often more explicit, and more immediate, are all those fine gradations offered by comparisons of occupation, income, consumption and lifestyle and other dimensions of perceived status. Within this more Weberian tradition, Lockwood (1958) was one of the first to attempt to demarcate those in the middle strata from the traditional working class by virtue of the status distinctions offered by their position within the labour market and aspects of their job situation. Lockwood was not saying that his clerks were not workers, simply that the 'blackcoated worker' distinguished himself (and it was a 'him' then) from other workers through a number of key dimensions of status.

There is considerable evidence that, despite the increased consumption and decreased objective class markers located in the political rhetoric and practice of the Thatcher era (see Beynon, 1999; Bradley, 1996), individuals still hold a culturally based class identity. Scott (2002) notes that standard surveys have found over $90 \%$ of people in 
Work Employment and Society 23 (1) 2009. Accepted rev'd version.

Britain are still disposed to recognise the existence of classes and to allocate themselves into one of them. Almost half the population identify themselves as working class (even though objective markers would indicate a much lower percentage of people in this class), while a quarter identify themselves as middle class. In 1994, 51\% of those surveyed by Mori described themselves as working class; by 2002 it had increased to 68\%. Furthermore, Devine (1992) found that larger and larger groups of individuals were locating themselves in a broad category of the working/middle class (rather than specifically working class) with only the extremes of the very rich and very poor excluded.

If a 'new' occupational group such as software workers maintain the existence of social class in Britain in the new millennium and can locate themselves, albeit vaguely, within a class structure, this would lend support for a degree of social continuity rather than the paradigm shift that the 'after-class' models infer.

\section{Researching Software in Scotland}

This analysis of class derives from a study designed to explore the contemporary meaning of work for employees in Scotland. The project examined five software organizations which included one medium-sized independent software house (Omega), one software division of a large national communications company (Beta), and three independent, single product software firms ( $\mathrm{Pi}$, Lambda and Gamma). Close contact and data collection was maintained with each case study for at least four months.

Background data on company history, operating procedures, employment policies and staff characteristics were gathered as part of an intensive process of case study analysis and observation. All the organizations studied were representative of the sector by employing a combination of contractors (16\% of sample) and permanent employees $(84 \%$ of sample); comprising a majority of males $(72 \%$ overall, although Omega, Pi and Lambda employed between $32 \%$ and $41 \%$ females); and having a generally young workforce, with $73 \%$ under 40 . Only one of the organizations, Beta, was unionised. 
Work Employment and Society 23 (1) 2009. Accepted rev'd version.

Exploratory interviews took the form of work observation and focussed discussions with key groups of informants (management, employees and team leaders) and provided an initial discussion of the work process and issues around collective work, skills, and careers. In order to develop a more detailed understanding of how people experienced work we followed Goldthorpe et al, (1969) by engaging in a combination of home and workplace semi-structured interviews, for which we selected employees according to gender, age, job type and job/organizational level. For this paper we will focus on the responses to the questions about perceptions of society and status. We specifically asked if employees recognised divisions in society. The questions did not initially ask about class in order to avoid any bias in responses. Between 19 and 29 semi-standardized employee interviews were obtained for each company, except for the small start-up (Lambda) where three employees were thought to adequately represent the company.

Each interview was either transcribed verbatim or produced as research field notes and coded by the researchers. Key themes evolved from careful inductive coding. A qualitative data analysis software package (nVivo 1.2) was used both for data management and for data analysis. Out of a total of 76 interviews, 62 participants responded to questions of social class and class perception. Their interviews were subject to content analysis in order to indicate the more important components of respondents class perceptions; each interview quotation is labelled in this paper according to company and interview number.

\section{Findings}

\section{$\underline{\text { Awareness of Class and Perceptions of Class Structures }}$}

When interviewees were asked whether they saw status divisions existing in any meaningful form in Britain today two thirds said 'yes'. We followed this question by asking them about general perceptions of class structures, how software employees fit within these categories and where the individuals themselves felt they fitted within these groupings. The images of class structure held by Goldthorpe et al's (1969) 
Work Employment and Society 23 (1) 2009. Accepted rev'd version.

'affluent' workers formed three broad models: a 'power' model with two major classes were differentiated in terms of possession of power and authority, a 'prestige' model where three or more classes were differentiated in terms of aspects of lifestyle, and social background, and a 'money' model with one large central class plus one or more residual or elite classes, differentiated in terms of wealth, income and consumption standards. As explained below, we found slightly conflated version of these distinctions.

Goldthorpe et al. (1969, p. 147) found that 54\% of their manual participants felt that differences in income, wealth and standards of living were the most important determinant of class. We might expect, with the withering away of traditional class ideas, that for a sample of white-collar technical workers over forty years later, such a money model would be almost universal. However, as we shall see, this is far from the case. Although most respondents alluded to the manifestations/determinants of class e.g. family background, community, education and lifestyle, we can divide the responses into those that use traditional class terminology - upper class, middle class, working class - and those that talk in terms of rich and poor and/or mention money as the main divisor. As Platt (1971) and Savage (2005) identified when re-analysing the data from the Luton studies, participants often used money as a way of talking about power structures: wealth was often talked about hand-in-hand with discussion of the upper classes. Yet, we found that while these two categories are not entirely exclusive and some respondents, like Goldthorpe and Lockwood's, used both class terminology and money, $47 \%$ of respondents used something close to a traditional terminology and $39 \%$ had what we could call a 'pure' money model.

Of those using traditional terminology, many felt there was definitely an upper class and the majority used some variant of middle or middle-working. Few had such a whole-society image as this respondent:

'If you ask me what I see in Britain's society today, I would say there is still a kind of elite at the top who just have money and don't do anything sort of thing, there are wealthy professional people that are senior managers in companies like Beta and blue chip companies that obviously aren't.... the aristocracy or anything like that but it's a kind of new aristocracy of people who have got lots of money. There are people that are professionals like myself that are doing a job, working hard and trying to do as best as they can for themselves and their family. There are people that are doing what would 
Work Employment and Society 23 (1) 2009. Accepted rev'd version.

probably be classed as unskilled jobs, it's more like, you don't have a professional qualification to do it but nevertheless it's still an important job to society and I also feel there seems to be an increasing area of society that people seem to just say, oh well I'm going to just sit back and let the state fund my life sort of thing. Which I find a bit hard to accept.' [Beta: B-I04]

Two aspects of our responses are similar to those recorded nearly forty years ago.

Firstly, that there is a definite break between the upper class, and the rest:

'I think what you might call the upper class is still different because I think the difference in jump between middle and upper class is so big that you don't often get a step between them. I think you are talking about immensely rich people and often people not who are just very rich, yes it is not people who are very rich, it's people whose family have been very rich for a long time I think. So if I won the lottery tomorrow with $£ 20$ million I wouldn't suddenly consider myself upper class. ...... So I guess it's the middle and the bottom that are coming together but I view the top still as a different world almost'. [Gamma: G-I-11]

Secondly, that the border between middle and working-class is blurred and becoming more difficult to see; about half of those referring to the middle class mentioned (without being asked) that class divisions were narrowing. Again this parallels more recent findings by Devine (1992) and Savage (2000). A common response was that 'most people' were in the same class:

'I think it's eroded over the past years. It's become more like the American model where really money talks except in the higher end of society where there is still a class distinction. I think that line over where there is a class distinction moves up over the years. It matter still at the top end but, I mean from middle class and below (I) don't really think. I mean is there a middle class anymore, is there a definition between middle class and working class? I don't think there is anymore. There is just varying degrees of wealth........ Between upper class and the other classes, I think there is quite a clear distinction who you would put in the group and who you wouldn't, between middle class and working class I don't know.' [Beta: B-I-19]

Although money obviously figured highly, a number of other factors were regularly mentioned as determining class or position in society. Many respondents referred to multiple causes, with the most frequently cited influences being community/housing, education and existing profession, as the following example demonstrates.

'You know the whole sort of thing about being working class. You didn't own your own house. It was only nearer the end of my father's life that he bought his own house.' [Beta: B-I-12] 
Work Employment and Society 23 (1) 2009. Accepted rev'd version.

There was a repeated, unprompted, assertion from many respondents that they did not believe in 'class distinction'. They associated any discussion of class as representing snobbery and claimed that they 'treated everyone the same'.

(In response to question on whether class still exists) 'Not really. I mean it doesn't mean a lot to me. I mean I have got a sort of standard working class council house background and I've never let that hold me back in any kind of way. I don't wear it like a badge to say, 'oh look how well I've done'. You know that is my background and I don't give it an awful lot of thought and where people do wear it like a badge, then it irritates me. I don't think it really matters'. [Pi: P-I-3]

This issue emerged from at least twelve of the interviews. As the quote above illustrates, this lack of belief of existence of class may be attributable to what seems to be a significant element of social mobility among this group, outlined below. Ironically, many of those that denied the reality of class in contemporary society also described specific anchors defining their own class position or class origins.

\section{The Class Location and Class Identity of Software Workers}

The most interesting insights into class complexity in this group are provided by contrasting the responses on the class position of software developers as a group and their responses to questions on self-rated class. Although many respondents found the positioning of software workers difficult to articulate, of those that did attempt it, the almost unanimous label was that of middle class/professional and the most commonly offered reasons were education and income/lifestyle. Interestingly, not one of the interview participants situated software work amongst the working class.

Q: if you had to put software workers in some sort of social class, where would you place them?

M: I guess middle class now. In the old sort of lower-middle class - it still has not got the respect (like) being a lawyer'

[Beta: B-I-02]

Yet, there appeared to be some ambiguity as to what was meant by the middle or professional classes:

'I think they use the term professional for some careers, like doctors and lawyers and things like that, I think this is probably considered a professional occupation, but as far as I'm concerned professional just means you earn money for what you do. So it covers an awful lot of people' [Beta: B-I-09] 
Work Employment and Society 23 (1) 2009. Accepted rev'd version.

Indeed, this ambiguity is reflected in software employees' perceptions of their own personal class identity. As part of the interview process, when participants were asked to self-locate, of those who felt able to choose a class location, $38 \%$ felt that they were working class, $31 \%$ said middle class, $28 \%$ said 'professional' and $8 \%$ felt they were upper middle class. This corresponds to the findings from the Scottish Election Surveys of 1979 and 1997 which found that within every broad socio-economic group, the highest percentage of people called themselves working class.

There are contradictory findings from other studies as to the extent to which family environment determines class identity. Some studies have found that many people who are working class or from a working class background deliberately dis-identify with this categorisation (e.g. Skeggs, 1997; Devine, 1992). However, reporting on large scale surveys, Scott (2002) noted similar percentages of participants identifying themselves as working class as in our study.

Paterson et al $(2004$, p. 81) note 'the second half of the twentieth century was a period of probably unprecedented openness in the class structure, in the sense that it became normal for people to move into a better kind of job than their parents.' Yet, we found, despite evidence of this mobility, participants still interpreted class as being based on culturally significantly markers such as parent's profession/background or by explicit manifestations of lifestyle/wealth other than those that are purely wage related. These constructions of class identity are founded on the reproduction of class through cultural and economic symbols (Devine and Savage, 2000). Consequently, when the reasons given for class position are matched with self-location we find that three quarters of those who felt they were working class - regardless of their occupation and existing economic position - provided explanations that included historical or socially embedded factors such family background, upbringing, residence, or community. Despite the frequently stated perceptions of a middle class identity being tied up with home and car ownership and holidays abroad - 'the trappings of middle class life' [Omega: O-I-16] - many self-located on the basis of their parents' occupations, and their own and parents' political orientation. Our participants were often making a very explicit division between subjective and objective class positions. 
Work Employment and Society 23 (1) 2009. Accepted rev'd version.

'Oh yes. I'm definitely working class. Very definitely. My wife doesn't agree but I do because that's where I came from. My father was a miner and so, my mother worked in a shop, so I'm very definitely working class, and I work for a living and I have to work for a living, I've got no choice. So I'm very conscious of the class that I belong to...... By any standard of measure I am middle class, I own my own home, I've got two cars, my wife's professional and my son goes to one of those top schools, ... we both went to university and got degrees, we are probably in the top salary earners so we are middle class, but I personally don't believe that, I believe I'm working class. It's the background that I have. I'm true to the politics of the working class.' [Pi: P-I02]

Many of the respondents who realised that objectively they must be described as being middle-class, often wished that they could maintain a working class identity. This is clearly illustrated by the response given by a participant when asked to describe her class position.

'That would be middle class I think because I am married to an IT sales consultant as well, so we live in a nice house in Edinburgh. So I couldn't say working class anymore even though I would like to be still.' [Pi: P-I-10]

Although Goldthorpe et al (1969) argued that the differences between educational aspirations of the working and middle classes was the value placed on vocational rather than academic subjects, there is some evidence here, that those software workers who by any objective measure were situated in the middle strata, have come from backgrounds where academic qualifications were cherished. This may reflect the Scottish educational system as, according to the DfEE (1997), there has been an increasing inequality between educational attainment and social class in England. In Scotland, although a disparity still exists, there is steady progression in educational attainment of working class children with a continually decreasing gap between levels of academic accomplishment for the working and middle classes (Croxton, 2001). Nonetheless, those that identified themselves as middle class were still more likely to mention either education or income/lifestyle. Indeed, some middle-class self-locaters saw education and background as connected:

Q: What class would you put yourself in?

A: A fortunate class! Sort of a professional, educated kind of class, in that kind of sector I have been lucky that I have had a good education and I have used that to get a good job' [Pi: P-I-11] 
Work Employment and Society 23 (1) 2009. Accepted rev'd version.

Whatever employees viewed their existing class position to be, many of them felt that they had come from a working class background and that this was somehow compatible with a career as a software worker. Software work was typically viewed as different to the traditional professions and there was an implicit assumption by many of the participants that it was more appropriate for them to enter this form of work than, for example, accountancy or medicine, as it was not such a significant transition from their position in the working classes.

'I don't think there is many people who come into software from the sort of upper middle classes, I think they tend to go for law and the professions.' [Pi: P-I-10]

For most employees there was a strong emphasis on the need for, and existence of professional community. Whilst trade union membership was low, employees for the most part demonstrated instrumental collectivism through membership of professional bodies and through Stephenson and Stewart's (2001) collectivism of everyday life.

'I think it's one big community almost. If I was to meet someone else who was

a software engineer you've automatically got something in common with them' [Beta: B-HI-O7]

\section{Discussion and Conclusions}

It has been argued 'Britain is not a deeply class conscious society' (Savage, 2000; p.40) and that 'people are reluctant to claim class identities' (Bottero, 2004; p.987). Yet we found that, regardless of whether participants instinctively offered class identities, they were still able to resort to class as a way of self-identification and as an explanatory framework for relative positions in society. Class maintained its role as a way of understanding social and political changes.

Whilst software work was unanimously positioned within the middle classes or professional classes, the self-location of software workers varied from working class to a minority in the upper middle classes. It could be argued that software work is attractive as it offers open-access socio-economic mobility to those with the necessary 
Work Employment and Society 23 (1) 2009. Accepted rev'd version.

talents without the significant value baggage which might be associated with the traditional professions. Our software respondents can reconcile their enhanced style of life with egalitarian feelings towards others and the necessity to treat all the same. At the same time, it allows people to become 'middle-class' if that is what they wish, or are happy with. This of course is not a new phenomenon: Mills (1951) half a century ago saw members of the 'new middle class' as likely to emerge out of the working class as educated labour.

The ambiguity in terms of self-location is akin to other arguments questioning the homogenous character of the 'new middle class' (Callinicos, 1983; p.85). Callinicos has argued that the middle classes embrace three class positions; senior managers and administrators, professional and managerial employees and lower profession such as teachers, nurses and social workers. The positioning of software work as an occupation in the middle strata is however, interesting in itself. Writers such as Mallet (1976) would argue that, particularly at the more routinised end, software workers are members of the 'new working class' regardless of their employment position in leading-edge capitalist organisations. This is not dissimilar to Smith's (1987, p.74) earlier conclusions that technical workers are 'not cut off from the working class' by credentialism or monopoly but, on the contrary were 'productive, non-supervisory wage labourers'. The tension between the objective location of software work and the subjective position of our participants is testament to the different dimensions along which class is experienced. As most respondents applied a money model then the middle class position of software work seems logical, but their self-location as working class could be reflective of an awareness of their position as white collar production workers and of the cultural dimensions of first generational social mobility.

The class position and class identity of software workers is less clear than that of the traditional professions and is more varied and less determined by occupation, not only due to the confused position of software work but also as a response to the 'softer' entry routes and the associated breadth of background of the software workers. Darr and Warhurst (2008) argue that knowledge workers and the 'new middle class' are so varied they are difficult (or impossible) to discuss as a single grouping. Yet, it may be that for many working within the occupations embodied by these categories, class 
Work Employment and Society 23 (1) 2009. Accepted rev'd version.

position and perceptions of collectivism are determined by factors other than preconceived associations between an occupation and its class position. Although a high proportion of our sample viewed class in objective terms, particularly in financial terms, a high proportion self-located using very different criteria. Moreover, whilst the majority of our participants, as with other studies (e.g. Devine, 1992), perceived that there was a merging of the working and middle classes, the most popular category for self-location was the working class.

There are a number of factors that could have influenced the almost forty percent of participants that located themselves as working class. Firstly, as we have already noted, software work could be described as 'white collar manufacturing', and may have more in common with traditional manual and technical work that professional labour $^{1}$. Whilst our participants are comparatively affluent, they still sell their labour power in order to survive. Similar to general managers, doctors or academics, our software workers face competing pressures: on the one hand, their financial and cultural status means that they buy into the system while, on the other hand, because they sell their labour power, they too can find themselves in conflict with the system.

Secondly, there is the influence of nationality. Many of our participants distinguished between the class structures in Scotland and the class structures in England through which class was frequently perceived as being a 'snobby' English phenomenon. Other research has found a dominance of the working class identity in Scotland. The election survey of 1997 asked questions about individuals' objective and subjective class identity and their class mobility. Of those who had been born into, and remained in the middle classes, $44 \%$ defined themselves as working class while, of those who have moved from a working class background to the middle classes, $80 \%$ still called themselves working class. In England there is a greater propensity for those that had moved from the working into the middle classes to define themselves as being middle class (Paterson et al, 2004).

Thirdly, many of the interview responses - as other writers have also found (e.g. Woodin, 2005) - associated collectivism with the working class and individualism

\footnotetext{
${ }^{1}$ A thorough account of de-skilling in software work can be found in Marks and Scholarios (2006).
} 
Work Employment and Society 23 (1) 2009. Accepted rev'd version.

with the middle and upper classes. That is, explanations of working class identity were associated, as stated before, with collective entities such as trade unions, socialism and even religion. Indeed, Hyman et al (2004) found that despite low levels of trade union membership, software workers maintain a collectivist orientation to work, evidenced by participation in occupational communities. This is perhaps a relic of the values from the communities from which our participants originated and the sense of cohesiveness found in classic industrial populations (see e.g. Brown and Brannen, 1970; Salaman, 1974). As Baldry et al (2007) suggest, old communities may be being replaced by contemporary ones which embody the same or similar aspects of identity and solidarity. Hence, we refute claims from writers such as Bradley (2000, p.255) that there is a shift 'away from class-based collectivism towards greater social individualism'.

Consequently, there is some evidence to support the culturalist arguments made by writers such as Devine (1998) that class is not solely manifest in objective presentations of wealth and status. Yet, class continues to be a significant aspect of a broad range of influences on identity (Savage, 2004). It has, however, become in part, a subjective notion which is based on a shared identity founded in perceptions of experiences, loyalties and values. This was the case, at least, in our sample, many of whom were the first generation of 'the middle strata'.

That is not to say that similar identities will be presented in the children or grandchildren of our participants. With the rapidly expanding middle/professional classes, associations with the objective measures and subjective attitudes of the 'traditional' working classes become more distant. Less than half of those born into the middle classes defined themselves as working class. Perhaps with further generations, the explicit expressions of the working class will become less salient to the social identities of individuals.

\section{Acknowledgements}

The work in this paper is derived from the project Employment and Working Life Beyond the Year 2000: Two Emerging Employment Sectors, ESRC Award No: L212252006. 
Work Employment and Society 23 (1) 2009. Accepted rev'd version.

Sincere thanks are offered to the editors and to the anonymous referees for their helpful comments on earlier drafts of this paper.

\section{REFERENCES}

Barrett, R. (2001) 'Labouring under an illusion? The labour process of software development in the Australian information industry', New Technology, Work and Employment 16 (1): 18-34.

Baldry, C., Bain, P., Bunzel, D., Gilbert, K., Hyman, J., Marks, A., Mulvey, G., Scholarios, D., Taylor, P., Watson, A. (2007) The Meaning of Work in the New Economy. London: Palgrave.

Bauman, Z. (1998) Work, consumerism and the new poor. OUP: Buckingham.

Bell, D (1979) 'The Social Framework of the Information Society', in Dertouzous and Moses (eds) The Computer Age: A Twenty Year View, 163-212. MIT Press: Cambridge.

Bell, D. (1980). The social framework of the information society, in T.Forester (ed.) The Microelectronics Revolution. Oxford: Blackwell.

Bulmer, M. (ed.) (1975) Working-Class Images of Society. London.

Bonney, N. (2007) Gender, employment and social class, Work, Employment and Society, 21(1), 143-155.

Bottero, W. (2004) 'Class Identities and the Identity of Class', Sociology, 38 (5): 985 1004.

Byrne, D. (2005) 'Class, Culture and Identity: A Reflection on Absences Against Presences', Sociology 39 (5): 807-816.

Bradley, H., Erickson, M., Stephenson, C., and Williams, S. (2000) Myths at Work. Cambridge: Polity.

Brown R.K. and Brannen, P. (1970) 'Social Relations and Social Perspectives Among Shipbuilding Workers - a Preliminary Statement. Part I' Sociology 4 (I), Part II Sociology 4 (ii).

Callinicos, A. (1983) Marxism and Philosophy. Clarendon Press: Oxford.

Crompton, R. (1998) Class and Stratification. 2nd Edition: Cambridge: Polity.

Crompton, R. and Scott, J. (2005) 'Class analysis, beyond the cultural turn', in F. Devine, et al. (eds) Rethinking Class, Palgrave: Basingstoke 
Work Employment and Society 23 (1) 2009. Accepted rev'd version.

Darr, A. and Warhurst, C. (2008) 'Assumptions, Assertions and the Need for Evidence: Dubugging Debates about Knowledge Workers', Current Sociology, 56(1): 25-45.

Devine, F. (1992) Affluent Workers Revisited: Privatism and the Working-Class. Edinburgh: Edinburgh University Press.

Devine, F. (1998) 'Class Analysis and the Stability of Class Relations', Sociology 32(1): $23-42$.

Devine, F. and Savage, M. (2000) 'Conclusion: Renewing Class Analysis', in R. Crompton et al. (eds) Renewing Class Analysis, p. 184-199. Oxford: Blackwell.

Department for Education \& Employment (DfEE) (1997) Excellence in Schools. Cm 3681. London: HMSO.

Drucker, P. (1998) 'The future that has already happened,' The Futurist, 32 (8): 1618.

Ehrenreich, B., and Ehrenreich, J. (1979) 'The professional-managerial class', in Walker, P. (ed), Between Labour and Capital, 5-45. London: Harvester.

Gallie, D. (2000) 'The Labour Force', in A.H. Halsey and J. Webb (eds) TwentiethCentuary British Social Trends, 281-323. London:Mcmillan.

Giddens, A. (1990) The Consequences of Modernity. Cambridge: Polity.

Giddens, A. (1991) Structuration Theory: Past, Present, Future. In C. Bryant \& D. Jary (eds.) Giddens' Theory of Structuration: A Critical Appreciation, 201-221. London: Routledge.

Goldthorpe, J., Lockwood, D., Bechhofer., F., Platt, J. (1969) The Affluent Worker in the Class Structure. Cambridge: Cambridge University Press

Goldthorpe J.H., (1996) 'Class analysis and the reorientation of class theory : the case of persisting differentials in educational attainment', British Journal of Sociology 47 (3): 481-505.

Goldthorpe, J.H. (1987) Social Mobility and Class Structure. Oxford: Clarendon Press.

Hyman, J., Lockyer, C., Marks, A., and Scholarios, D. (2004) 'Needing a New Programme? Union Membership and Attitudes towards Unions amongst Software Workers', in W. Brown et al (eds) The Future of Worker Representation. London: Palgrave.

Hyman, R. (1983) 'White-collar workers and theories of class' in R. Hyman and R. Price (eds) The new working class? White collar workers and their organisations. Basingstoke: Macmillan. 
Work Employment and Society 23 (1) 2009. Accepted rev'd version.

Klingender, F.D. (1935) 'Clerks as proletarians' in R. Hyman and R. Price (eds) (1983) The new working class? White collar workers and their organisations. Basingstoke: Macmillan.

Kraft, P. and Dubnoff, S. (1986) 'Job content, fragmentation and control in software work', Industrial Relations 25 (2): 184-196.

Lewin, C. and Orleans, M. (2000) The Class Situation of Information Specialists: A Case Analysis. Sociological Research Online 5:3. <http://www.socresonline.org.uk/5/3/levin.html>.

Lockwood D (1958) The black-coated worker: a study of class consciousness. London: Aleen and Unwin.

McBride, J. (2008) 'Mapping worker collectivism: some evidence from River Tyne industries in the North East of England', Work, Employment and Society, 20(3): 583391.

McCrone,D., Brown, A., Surridge, P., and Thomson, K. (1997) Scottish Election Survey, 1997, UKDA 3389.

Mallet, S. (1975) The New Working Class. Nottingham: Spokesman.

Marks, A., and Scholarios, D. (2007) 'Revisiting Technical Workers: The Professional and Organizational Identities in the Software Industry', New Technology, Work and Employment, 22 (2): 98-117.

Marshall, G.D., Rose, D., Vogler, C., and Newby, H. (1988) Social Class in Modern Britain. London: Hutchinson.

Metochi, M. (2002) 'The Influence of Leadership and Member Attitudes in Understanding the Nature of Union Participation', British Journal of Industrial Relations 40(1): 87-111.

Miller, W.L. and Brand, J.A. (1979) Scottish Election Study, 1979. UKDA 1604.

Mills, C. W. (1951) White Collar. Oxford: OUP.

Office of Population, Census and Surveys (2001) Labour Force Survey, 2001, London: HMSO.

Pakulski, J., and Waters, M.J. (1996) 'The reshaping and dissolution of social class in advanced society', Theory and Society, 25: 667-691.

Paterson, L.., Bechhofer, F., and McCrone, D. (2004) Living in Scotland: Social and Economic Change since 1980. Edinburgh: Edinburgh University Press.

Platt, J. (1971) 'Variations in Answers to Different Questions on Perceptions of Class', Sociological Review 19: 409-419. 
Work Employment and Society 23 (1) 2009. Accepted rev'd version.

Poulantzas, N. (1975) Classes in Contemporary Capitalism. London: Verson

Reay, D. (1998) 'Rethinking Social Class: Qualitative Perspectives on Class and Gender' Sociology 32(2): 259-275.

Rifkin, J. (1995) The End of Work: The Decline of the Global Labour Force and the Dawn of the Post-Market Era. New York: G.P. Putnam's Sons.

Rousseau, D. M. (1998) 'Why workers still identify with organisations, Journal of Organisational Behaviour' (19): 217-233.

Salaman, G. (1974) Community and Occupation: an Exploration of Work/Leisure Relationships. Cambridge: CUP.

Savage, M. (2005) 'Working-Class Identities in the 1960s: Revisiting the Affluent Worker Study', Sociology, 39 (5): 929-946.

Savage, M. (2000) Class Analysis and Social Transformation. Buckingham: OUP

Scott, J. (2002) 'Social class and stratification', Acta Sociologica, 45 (2): 23-35.

Skeggs, B. (1997) Formations of Class and Gender: Becoming Respectable. London: Sage.

Smith, C. (1987) Technical Workers: Class, Labour and Trade Unionism. London: Macmillan.

Smith, C. and Willmott, H. (1991). The new middle class and the labour process' in: Smith C, Knights D and Willmott $\mathrm{H}$ (eds.) White Collar Work: the non-manual labour process, Basingstoke: Macmillan.

Surridge, P. (2007) 'Class belonging: a quantitative exploration of identity and consciousness', The British Journal of Sociology, 58(2): 207-226.

Stanworth, C. (2000) 'Women and work in the information age', Gender, Work and Organization 7(1): 20-31.

Stephenson, C. and Stewart, P. (2001) The Whispering Shadow: Collectivism and Individualism at Ikeda-Hoover and Nissan UK, Sociological Research Online 6(3): 115 .

Turner, J. C. (1982) 'Towards a cognitive redefinition of the social group', in H. Tajfel (ed.) Social identity and Intergroup behaviour. Cambridge:Cambridge University Press.

Turner, J.C. (1984) 'Social identification and psychological group formation', in Tajfel, H. (ed.), The social dimension, vol.2. Cambridge: Cambridge University Press. 
Work Employment and Society 23 (1) 2009. Accepted rev'd version.

Tyler, T.R., and Blader, S.L. (2001) 'Identity and co-operative behaviour in groups', Group Processes and Intergroup Relations, 4 (3): 207-226.

Walkerdine, V. and Lucey, H. (1989) Democracy in the Kitchen: Regulating Mothers and Socialising Daughters. London: Virago.

Woodin, T. (2005) 'Muddying the Waters: Changes in Class and Identity in a Working-Class Cultural Organization. Sociology’, 39 (5): 1001-1018. 
Work Employment and Society 23 (1) 2009. Accepted rev'd version. 